\title{
PENGARUH PRICE EARNING RATIO DAN PRICE BOOK VALUE TERHADAP HARGA SAHAM PADA SUB SEKTOR SEMEN YANG GO PUBLIC DI BURSA EFEK INDONESIA
}

\author{
Pemy Christiaan ${ }^{1}$. Rusdi Abdulkarim ${ }^{2}$ \\ ${ }^{1}$ Prodi Manajemen Universitas Ichsan Goronralo \\ ${ }^{2}$ Program Studi Akuntansi Universitas Ichsan Gorontalo \\ Email : pemychristiaan1802@gmail.com ${ }^{1}$, rusdiyudhani@gmail.com²
}

\begin{abstract}
Abstrak
Penelitian ini bertujuan untuk mengetahui menganalisis seberapa besar Pengaruh Price Earning Ratio dan Price Book Value secara simultan maupun secara parsial terhadap Harga Saham pada Sub Sektor Semen. Penelitian adalah penelitian kuantitatif, dengan menggunakan menggunakan analisis rasio. Metode analisis menggunakan regresi linier berganda, hasil penelitian menunjukkan bahwa Price Earning Ratio dan Price Book Value secara simultan berpengaruh terhadap Harga Saham Sub Sektor Semen sebesar 0,297 (29,7\%), Net Price Earning Ratio secara parsial berpengaruh positif dan tidak signifikan terhadap Harga Saham Sub Sektor Semen sebesar 0,188 (18,8\%), Price Book Value secara parsial berpengaruh negatif dan signifikan terhadap Harga Saham Sub Sektor Semen sebesar -79,864 (-798,64\%).
\end{abstract}

Kata Kunci: PER, PBV dan Harga Saham

Abstract

This study aims to determine how much influence is to determine how much influence Price Earning Ratio and Price Book Value simultaneously or partially on stock prices in the cement sub-sector. This research is a quantitative study, using ratio analysis. The analysis method uses multiple linear regression, the results show that the $N$ Price Earning Ratio and Price Book Value simultaneously affect the Cement Sub-Sector Stock Price of 0.297 (29.7\%), Partially Net Price Earning Ratio has a positive and insignificant effect on prices. Cement SubSector Shares amounted to 0.188 (18.8\%), the Price Book Value partially has a negative and significant effect on the Cement Sub-Sector Stock Price of -79.864 (-798.64\%).

Keywords: PER, PBV and Stock Price

\section{PENDAHULUAN}

Pasar modal memegang peranan penting dalam perekonomian suatu negara, karena pasar modal dapat dijadikan sebagai tempat bertemunya pihak yang kelebihan dana (investor) dan pihak yang membutuhkan dana (emiten). Selain itu, pasar modal juga memberikan kemungkinan dan peluang bagi investor untuk memperoleh pengembalian (return) yang diharapkan.

Keputusan investasi investor harus didasarkan pada pemahaman investor sendiri tentang evolusi harga saham perusahaan sebagai tujuan investasi. Hal ini untuk memungkinkan investor memperoleh tingkat pengembalian yang diharapkan dengan risiko minimal. Ada dua bentuk pengembalian, yaitu dividen dan capital gain. Saat berinvestasi, investor perlu memahami saham mana yang undervalued dan karenanya layak dibeli dan saham mana yang dinilai terlalu tinggi dan layak dijual.

Harga saham adalah harga atau nilai mata uang yang bersedia Anda keluarkan untuk membeli saham tersebut. (Satono, 2016: 47). Pembentukan harga saham di pasar modal ditentukan oleh beberapa faktor, antara lain earning per share atau laba per saham, price-earnings atau price-earning ratio, dan suku bunga bebas risiko yang 
terukur. oleh suku bunga. Tingkat kepastian simpanan pemerintah dan operasional usaha.

Jadi Sutrisno (2017: 76) berpendapat bahwa "harga saham atau harga pasar saham adalah nilai saham yang dihasilkan dengan memperdagangkan saham tersebut di pasar sekunder". Saham umumnya diperdagangkan di bursa efek, dan harga pasar akan berubah dari waktu ke waktu, yang terkait dengan nilai saham. Secara singkat Jogiyanto mengungkapkan bahwa nilai yang terkait dengan saham adalah nilai buku, nilai pasar dan nilai intrinsik. Jogiyanto (2017:66) menjelaskan: "Nilai buku adalah nilai saham yang dihitung berdasarkan pembukuan perusahaan. Nilai pasar adalah nilai saham di pasar saham, dan nilai intrinsik adalah nilai saham yang sebenarnya.

Charge-earnings ratio (per) adalah ciri khas bagi investor untuk mengevaluasi kapasitas booming takdir suatu organisasi. di langkah dengan adalah yang paling luas digunakan untuk penilaian persediaan. karena rasio pendapatan-biaya (per) menunjukkan kepercayaan diri pasar terhadap potensi pemberi kerja, Anda juga dapat melihat evolusi biaya dan pendapatan saham perusahaan.

Susilawati (2016:57) mengemukakan bahwa P/E ratio memberikan petunjuk kepada para trader atau kemampuan investor bahwa harga saham berkorelasi positif, artinya jika harga saham naik maka harga saham malah akan booming. Semakin tinggi pendapatan yang diperoleh oleh majikan, itu akan memberikan pengembalian yang cukup baik, memberikan tanda yang baik kepada para pedagang bahwa semakin banyak modal yang diinvestasikan, harga persediaan akan naik.

Selain itu, price-to-earnings ratio (PER) menggambarkan apresiasi profitabilitas perusahaan di pasar (Darmadji dan Fakrudin, 2011:156). Oleh karena itu, rasio ini menggambarkan kesediaan investor untuk membayar sejumlah tertentu untuk setiap rupiah pendapatan perusahaan. Jadi bagi investor, semakin tinggi rasio $\mathrm{P} / \mathrm{E}$, semakin besar pertumbuhan laba yang diharapkan. Dengan cara ini, price-to-earning ratio adalah perbandingan antara harga pasar berbagai saham (harga pasar Fahmi (2014:289)). Rumus untuk menghitung rasio harga terhadap pendapatan (PER) adalah:

$\mathrm{PER}=\frac{\text { Market Price Pershare }}{\text { Earning Pershare }}$

\section{Keterangan}

PER = Price Earning Ratio

MPS = Market Price Pershare atau harga pasar persaham

EPS = Earning Persahare atau laba perlembar saham

Laba per saham adalah indeks yang menggambarkan jumlah rupiah yang diperoleh per saham biasa (Syamsuddin, 2016: 66). Jadi, secara umum, manajemen perusahaan, pemegang saham biasa, dan pemegang saham potensial sangat tertarik pada laba per saham. Earning per share merupakan salah satu indikator keberhasilan suatu perusahaan.

Jadi, Tandelilin (2017:384) Laba per saham (EPS) adalah sebagai berikut: "Laba bersih yang dibagikan kepada pemegang saham dibagi dengan jumlah saham perusahaan" ditambah Tandelin (2017:384), rumus perhitungannya adalah utilitas perusahaan untuk dibagikan sebagai berikut: 


$$
\boldsymbol{E P S}=\frac{\text { Laba bersih setelah pajak }}{\text { Jumlah saham yang beredar }}
$$

Tabel 1.

Prosedur Pengambilan Keputusan Investasi Berdasarkan dengan Pendekatan Price Earning Ratio (PER)

\begin{tabular}{|c|c|c|}
\hline Keterangan & Kondisi Saham & Keputusan Investasi \\
\hline Nilai Intrinsik > Nilai Pasar & Undervalued & Membeli Saham \\
\hline Nilai Intrinsik < Nilai Pasar & Overvalued & Menjual Saham \\
\hline Nilai Intrinsik = Nilai Pasar & Correctly Valued & Menahan Saham \\
\hline
\end{tabular}

Sumber : Husnan (2015:233)

Nilai buku atau book value adalah nilai modal dibagi dengan jumlah saham yang ada. Prasangka mengatakan bahwa nilai buku adalah nilai modal per saham. Ekuitas diperoleh dari selisih antara total aset dikurangi kewajiban. Secara teori, ini adalah nilai yang akan diterima pemegang saham ketika perusahaan dilikuidasi. Jadi ini adalah nilai buku yang sangat penting, lihat laba atas investasi.

Syamsudin (2016:75) menjelaskan bahwa konstruk nilai nilai dapat berupa hubungan yang menggambarkan sejauh mana pasar telah mengapresiasi nilai saham suatu perusahaan. semakin tinggi PBV, semakin besar kepercayaan pasar terhadap prospek perusahaan. Untuk korporasi dengan kinerja yang masuk akal, indeks biasanya dapat mencapai cukup satu, menunjukkan bahwa harga pasar lebih besar dari nilainya (Jogiyanto, 2017: 79).

Sawir (2015:22) berpendapat bahwa hubungan harga/nilai buku menggambarkan nilai pasar keuangan organisasi yang mengelola dan mengoperasikan perusahaan (going concern). Perusahaan yang dikelola dengan baik dengan manajer yang kuat dan organisasi yang dikelola dengan baik tidak sama dengan nilai buku aset fisik.

Di sisi lain, saham dengan PBV tinggi tidak berarti saham tersebut dinilai terlalu tinggi, karena perusahaan mungkin memiliki prospek dan kinerja yang baik, serta merek yang diakui. Alhasil, keduanya membuat harga saham lebih tinggi dari saham dengan PBV lebih rendah namun outlook lebih rendah. Dalam Fahmi (2014:84), rumus untuk menghitung nilai buku (PBV) adalah sebagai berikut:

$$
\mathrm{PBV}=\frac{\text { Market price per share }}{\text { Book value per share Of Commonstock }}
$$

Keterangan :

$\mathrm{PBV}=$ Price Book Value

MPS = Market Price Pershare atau harga pasar per saham

BVS = Book Value Pershare atau nilai buku per saham

Ketika kita menggunakan metode nilai buku harga untuk menentukan posisi saham, kita tidak mencari nilai intrinsik yang diamati, tetapi kita menghitung nilai PBV 
dan kemudian menggunakan 1 sebagai nilai pisah untuk mengukur harga saham. Saham dengan harga tinggi atau rendah. Harga saham adalah nilai PBV lebih besar dari 1, yaitu nilai pasar lebih besar dari nilai buku. (Overvalued) Sebaliknya, jika nilai PBV kurang dari 1, berarti nilai pasar saham lebih kecil dari nilai buku (undervalued). Keputusan ini didasarkan pada teori yang dikemukakan oleh Husnan (2015: 27).

Tandelilin (2017: 323) juga mengatakan hal yang sama. "Idealnya, dibandingkan dengan nilai buku aset, harga pasar saham bank akan mendekati saham dengan rasio price-to-book yang lebih rendah. Itu harus dibeli dengan tingkat risiko yang lebih tinggi. Tingkat pengembalian."

Tabel 2.

Prosedur Pengambilan Keputusan Investasi Berdasarkan dengan Pendekatan Price Book Value (PBV)

\begin{tabular}{|c|c|c|}
\hline Keterangan & Kondisi Saham & Keputusan Investasi \\
\hline $\mathrm{PBV}>1$ & Overvalued & Menjual Saham \\
\hline $\mathrm{PBV}=1$ & Fairvalued & Menahan Saham \\
\hline $\mathrm{PBV}<1$ & Undervalued & Membeli Saham \\
\hline
\end{tabular}

Sumber : Husnan (2015:233)

\section{KERANGKA PEMIKIRAN}

Berdasar pada uraian diatas, maka disusun konsep kerangka pemikiran digambarkan sebagi berikut :

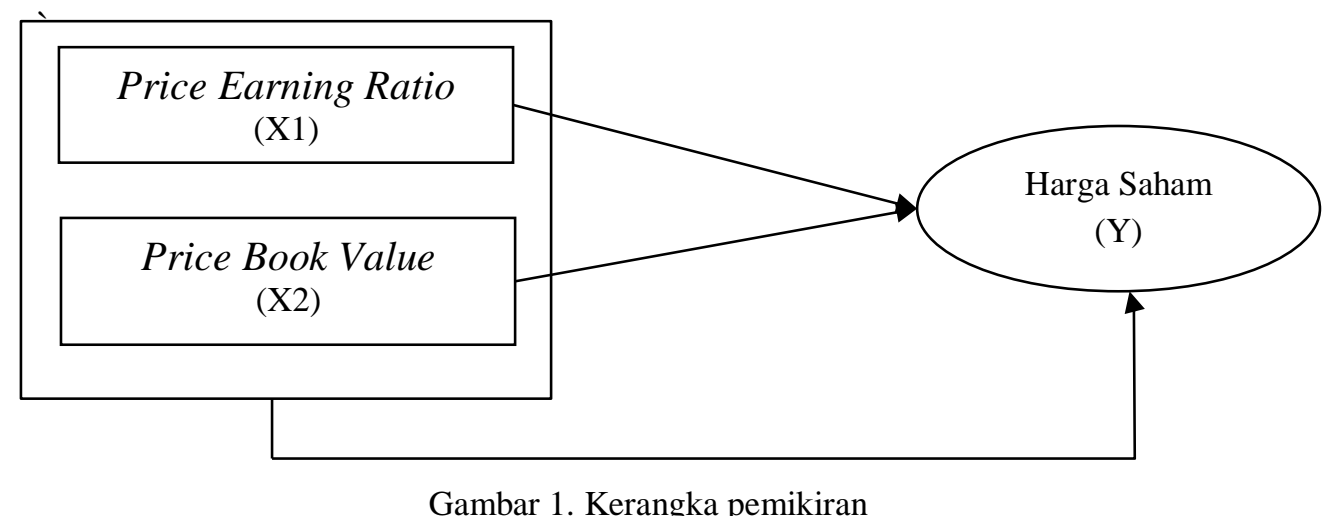

Berdasarkan perumusan masalah dan kerangka pemikiran diatas maka hipotesis yang diajukan penulis yaitu :

1. Price Earning Ratio (X1) dan Price Book Value (X2) secara parsial berpengaruh positif terhadap Harga Saham (Y) pada Sub Sektor Semen yang Go Publik di Bursa Efek Indonesia.

2. Price Earning Ratio (X1) dan Price Book Value (X2) secara simultan berpengaruh positif terhadap Harga Saham (Y) pada Sub Sektor Semen yang Go Publik di Bursa Efek Indonesia

\section{METODE PENETILIAN}


Metode yang digunakan dalam survei ini adalah survei kuesioner. Riduwan (2015: 49) mengemukakan bahwa penelitian survei dilakukan pada populasi besar dan kecil, tetapi data penelitiannya adalah data sampel yang diambil dari populasi tersebut. Penelitian survei biasanya menggunakan kuesioner sebagai alat pengumpulan data utama.

Teknologi analisis data menggunakan analisis regresi linier berganda untuk melakukan uji tebakan klasik pada data dari penelitian sebelumnya. Uji hipotesis digunakan untuk membuktikan hubungan secara parsial, sedangkan uji f digunakan untuk mengetahui hubungan sekaligus. Analisis signifikansi dalam penelitian ini menggunakan uji koefisien determinasi (R-kuadrat).

\section{HASIL PENELITIAN DAN PEMBAHASAN \\ Hasil penelitian}

Data yang digunakan pada penelitian, maka diperoleh laporan keuangan Sektor Sektor Semen, dari tahun 2015 sampai tahun 2019, sebagai tolok ukur untuk menilai kondisi keuangan perusahaan. Tolak ukur yang digunakan dalam penelitian adalah pengukuran kinerja keuangan dengan pendekatan analisis pengaruh Price Earning Pershare (PER), Price Book Value (PBV) terhadap Harga Saham. Berikut daftar tabelnya :

Tabel 3.

Tabel perhitungang PER,PBV dan Harga Saham

\begin{tabular}{|c|c|c|c|}
\hline No & PER & PBV & Harga Saham \\
\hline 1 & 73,3 & 15,17 & 1.503 \\
\hline 2 & 37,2 & 16,56 & 1.476 \\
\hline 3 & 18,4 & 11,97 & 1.504 \\
\hline 4 & 14,7 & 11,91 & 1.680 \\
\hline 5 & 76,2 & 13,30 & 1.758 \\
\hline 6 & 33,1 & 13,94 & 1.617 \\
\hline 7 & 21,3 & 12,67 & 1.700 \\
\hline 8 & 17,5 & 13,80 & 1.812 \\
\hline 9 & 70,4 & 11,67 & 1.878 \\
\hline 10 & 33,3 & 13,17 & 1.585 \\
\hline 11 & 18,8 & 9,88 & 1.665 \\
\hline 12 & 18,9 & 12,80 & 1.744 \\
\hline 13 & 75,8 & 10,87 & 1.814 \\
\hline 14 & 25,6 & 9,32 & 1.810 \\
\hline 15 & 20,3 & 9,32 & 1.862 \\
\hline 16 & 14,6 & 8,06 & 1.911 \\
\hline 17 & 30,6 & 8,53 & 1.947 \\
\hline 18 & 75,3 & 10,69 & 1.727 \\
\hline 19 & 110,2 & 10,72 & 1.764 \\
\hline 20 & 43,4 & 12,23 & 1.795 \\
\hline 22 & 33,5 & 0,24 & 2.394 \\
\hline 23 & 14,6 & 0,16 & 2.312 \\
\hline 24 & 8,9 & 0,13 & 2.508 \\
\hline 25 & 54,0 & 0,17 & 2.505 \\
\hline 26 & 29,8 & 0,15 & 2.554 \\
\hline & & & \\
\hline
\end{tabular}




\begin{tabular}{|c|c|c|c|}
\hline No & PER & PBV & Harga Saham \\
\hline 27 & 17,0 & 0,14 & 2.653 \\
\hline 28 & 11,2 & 0,14 & 2.762 \\
\hline 29 & 43,8 & 0,13 & 2.708 \\
\hline 30 & 18,0 & 0,11 & 2.804 \\
\hline 31 & 10,1 & 0,09 & 2.914 \\
\hline 32 & 8,1 & 0,10 & 2.998 \\
\hline 33 & 13,3 & 0,12 & 3.467 \\
\hline 34 & 60,0 & 0,20 & 2.998 \\
\hline 35 & 89,4 & 0,52 & 3.072 \\
\hline 36 & 139,5 & 0,88 & 3.172 \\
\hline 37 & 116,0 & 1,09 & 3.205 \\
\hline 38 & 53,2 & 0,96 & 3.331 \\
\hline 39 & 309,1 & 1,01 & 3.379 \\
\hline 40 & 126,7 & 1,10 & 3.469 \\
\hline 41 & 85,1 & 5,41 & 3.274 \\
\hline 42 & 39,2 & 5,48 & 3.122 \\
\hline 43 & 19,7 & 3,89 & 3.340 \\
\hline 44 & 15,6 & 3,85 & 3.676 \\
\hline 45 & 71,8 & 4,55 & 3.476 \\
\hline 46 & 31,7 & 4,03 & 3.743 \\
\hline 47 & 22,4 & 3,84 & 4.020 \\
\hline 48 & 17,3 & 3,84 & 4.215 \\
\hline 49 & 67,9 & 3,07 & 4.448 \\
\hline 50 & 32,6 & 2,83 & 4.247 \\
\hline 51 & 16,8 & 2,04 & 4.440 \\
\hline 52 & 15,0 & 2,46 & 4.626 \\
\hline 53 & 58,5 & 2,20 & 4.626 \\
\hline 54 & 28,2 & 2,01 & 4.646 \\
\hline 55 & 20,4 & 2,10 & 4.803 \\
\hline 56 & 12,0 & 1,78 & 5.155 \\
\hline 57 & 71,4 & 1,81 & 4.964 \\
\hline 58 & 54,3 & 1,99 & 5.014 \\
\hline 59 & 41,2 & 1,99 & 5.083 \\
\hline 60 & 29,1 & 1,93 & 5.132 \\
\hline 61 & 42,9 & 3,21 & 1.122 \\
\hline 62 & 40,2 & 2,21 & 1.111 \\
\hline 63 & 30,4 & 2,16 & 1.097 \\
\hline 64 & 18,3 & 1,99 & 1.145 \\
\hline 65 & 65,7 & 2,33 & 1.184 \\
\hline 66 & 44,5 & 2,28 & 1.151 \\
\hline 67 & 35,1 & 2,23 & 1.167 \\
\hline 68 & 25,1 & 1,91 & 1.143 \\
\hline 69 & 382,5 & 1,33 & 1.147 \\
\hline 70 & $(83,3)$ & 1,41 & 1.065 \\
\hline 71 & $(20,5)$ & 0,97 & 1.035 \\
\hline 72 & 43,3 & 0,90 & 1.103 \\
\hline
\end{tabular}




\begin{tabular}{|c|c|c|c|}
\hline No & PER & PBV & Harga Saham \\
\hline 73 & 118,9 & 0,96 & 1.112 \\
\hline 74 & $(150,7)$ & 0,98 & 1.081 \\
\hline 75 & $(49,3)$ & 0,97 & 1.067 \\
\hline 76 & $(24,3)$ & 0,86 & 1.052 \\
\hline 77 & $(60,3)$ & 0,87 & 1.037 \\
\hline 78 & $(13,2)$ & 0,76 & 992 \\
\hline
\end{tabular}

Data diolah kembali : 2021

\section{Uji Normalitas.}

Uji normalitas adalah untuk memeriksa apakah variabel pengganggu atau variabel residual dalam model regresi berdistribusi normal (Sugiyono: 2018). Model regresi yang baik adalah model dengan distribusi data normal atau mendekati normal. Dalam penelitian ini digunakan metode uji normalitas KolomogorovSmirnov (KS) non parametrik. Uji KS ini untuk mengamati nilai probabilitas signifikansi data residual. Jika angka probabilitasnya lebih kecil dari 0,05, maka variabel tersebut tidak berdistribusi normal. Sebaliknya, jika angka probabilitas lebih besar dari 0,05 maka Ha ditolak, hal ini menunjukkan bahwa data berdistribusi normal. Hasil uji normalitas dari penelitian ini ditunjukkan pada tabel di bawah ini.

Tabel 4.

Uji Normalitas

(One-Sample Kolmogorov-Smirnov Test

\begin{tabular}{|c|c|}
\hline & $\begin{array}{c}\text { Unstandardized } \\
\text { Residual }\end{array}$ \\
\hline $\begin{array}{cc}\text { N } & \text { Mean } \\
\text { Normal Parameters }^{\mathrm{a}, \mathrm{b}} & \text { Std. Deviation } \\
& \text { Absolute } \\
\text { Most Extreme Differences } & \text { Positive } \\
& \text { Negative } \\
\text { Kolmogorov-Smirnov Z } & \\
\text { Asymp. Sig. (2-tailed) } & \end{array}$ & $\begin{array}{c}78 \\
, 0000000 \\
1223,73852890 \\
, 123 \\
, 123 \\
-, 109 \\
1,088 \\
, 187\end{array}$ \\
\hline
\end{tabular}

a. Test distribution is Normal.

b. Calculated from data.

Tabel diatas menunjukan bahwa secara keseluruhan dilihat dari nilai residual, memiliki nilai alpha sebesar 0,187 . Kriteria pengambilan keputusan dat berdistribusi normal syaratnya adalah jika memiliki nilai signifkansi > alpha yang ditetapkan yaitu biasanya 5\% (0,05), Kurniawan (2014: 164). Dengan demikian disimpulkan bahwa data memiliki distribusi normal, karena memiliki sig lebih besar dari nilai yaitu yaitu 0,187.

\section{Uji Multikolinearitas.}

Tujuan pengujian adalah untuk menguji apakah ada korelasi antara variabel bebas dalam model regresi. Tergantung pada nilai VIF, hasil uji multikolinearitas dapat dilihat. Jika nilai VIF lebih besar dari 10, maka terjadi multikolinearitas antar variabel bebas; jika nilai VIF kurang dari 10 maka tidak terjadi multikolinearitas antar variabel bebas (Ghozali, 2018; 87). Hasil uji multikolinearitas adalah sebagai berikut:

\section{Tabel 5.}




\section{Uji multikolinearitas}

\begin{tabular}{|l|c|c|c|}
\hline \multicolumn{1}{|c|}{ Variabel Bebas } & Tolenrance & V I F & Keterangan \\
\hline Price Earning Pershare & 0,998 & $1,00 \mathrm{o} 2$ & Non Multikolineritas \\
\hline Price Book Value & 0,998 & 1,0002 & Non Multikolineritas \\
\hline
\end{tabular}

Sumber : Data diolah tahun 2021

Berdasarkan hasil pengolahan data di atas dapat diketahui bahwa nilai tolerance model regresi penelitian ini adalah $<0>10$, sehingga dapat disimpulkan tidak terdapat multikolinearitas pada model regresi penelitian ini untuk melakukan regresi. model layak.

\section{Hasil Uji Hipotesis.}

\section{a. Analisis Regresi Liner Berganda}

Analisis regresi linier dilakukan untuk mengetahui Price Earning Pershare (x1) dan Price Book Value (x2) terhadap Harga Saham Sub Sektor Semen Yang Go Public di Bursa Efek Indonesia (Y). Model persamaan menggunakan analisis regresi linier berganda. Hasil yang diperoleh adalah sebagai berikut :

\section{Tabel 6. Regresi linier}

Coefficients $^{\mathrm{a}}$

\begin{tabular}{|c|c|c|c|c|c|c|}
\hline \multirow{2}{*}{\multicolumn{2}{|c|}{ Model }} & \multicolumn{2}{|c|}{$\begin{array}{c}\text { Unstandardized } \\
\text { Coefficients }\end{array}$} & $\begin{array}{c}\text { Standardized } \\
\text { Coefficients }\end{array}$ & \multirow[t]{2}{*}{$\mathrm{t}$} & \multirow[t]{2}{*}{ Sig. } \\
\hline & & $\mathrm{B}$ & Std. Error & Beta & & \\
\hline \multirow{3}{*}{1} & (Constant) & 2872,868 & 221,552 & & 12,967 & ,000 \\
\hline & PER &, 188 & 2,409 & ,009 & ,078 & ,938 \\
\hline & PBV & $-79,864$ & 29,747 &,- 296 & $-2,685$ & ,009 \\
\hline
\end{tabular}

a. Dependent Variable: Harga Saham

Berdasarkan hasil print out SPSS versi 21 for windows diperoleh persamaan regresi sebagai berikut :

$$
\mathrm{Y}=2872,868+0,188 \mathrm{X} 1-79.864 \mathrm{X} 2+0,703 \mathrm{e}
$$

Dari fungsi regresi tersebut di atas, maka diketahui bahwa:

1. Koefisien regresi berganda positif berarti variabel X1 meningkat satu satuan nilai dan berubah satu arah. Jika variabel lain tidak berpengaruh (nilai nol), maka harga saham sub industri semen akan naik sebesar 0,188 .

2. Koefisien regresi berganda negatif berarti jika variabel $X 2$ turun dalam satuan skor berarti terjadi perubahan satu arah. Jika variabel lain dianggap tidak terpengaruh (nilai nol), maka harga saham sub industri semen akan turun sebesar 79.864 .

3. Jika variabel $\mathrm{x} 1$ dan $\mathrm{x} 2$ dianggap tidak berpengaruh atau nilainya 0 , maka harga saham sub industri semen adalah 2.872.868. Hal ini menunjukkan bahwa tanpa variabel x1 dan x2 maka harga saham sub industri semen adalah 2.872.868.

\section{b. Uji Koefisian Determinasi (R2)}

Rangkuman model sama dengan uji R2 persamaan regresi linier. Untuk mengetahui seberapa besar kombinasi variabel bebas dapat menjelaskan perubahan variabel terikat. Dalam menghitung nilai koefisien determinasi, penelitian ini 
menggunakan nilai adjusted R-squared. Dari hasil pengolahan data diperoleh nilai koefisien determinasi sebagai berikut:

Tabel 7.

Koefisian Determinasi (R2) Model Summary ${ }^{b}$

\begin{tabular}{|l|r|r|r|r|}
\hline $\begin{array}{l}\text { Mode } \\
1\end{array}$ & R & R Square & $\begin{array}{c}\text { Adjusted R } \\
\text { Square }\end{array}$ & $\begin{array}{c}\text { Std. Error of } \\
\text { the Estimate }\end{array}$ \\
\hline 1 &, $297^{\mathrm{a}}$ &, 088 &, 064 & 1239,94769 \\
\hline
\end{tabular}

a. Predictors: (Constant), PBV, PER

b. Dependent Variable: Harga Saham

Model persamaan regresi menunjukkan bahwa nilai adjusted $\mathrm{R}$-square sebesar 0,088. Hal ini menerangkan bahwa variabel independen yaitu Price Earning Pershare (x1) dan Price Book Value (x2) dapat menjelaskan variabel dependen Harga Saham sebesar $88 \%$ sedangkan sisanya $12 \%$ dipengaruhi oleh faktor lain diluar penelitian ini.

\section{c. Uji Signifikasi Simultan (Uji Statistik F)}

Uji F merupakan tahap awal yang digunakan untuk mengetahui apakah model regresi yang diestimasi layak atau tidak. Jika nilai signifikansi $\mathrm{F}$ lebih kecil dari 0,05 $(\mathrm{p}<0,05)$, maka model regresi signifikan secara statistik dan layak digunakan. Dari hasil analisis regresi dapat diketahui bahwa nilai $\mathrm{F}$ adalah sebagai berikut:

Tabel 8. Hasil Uji Signifikansi Simultan (Uji F)

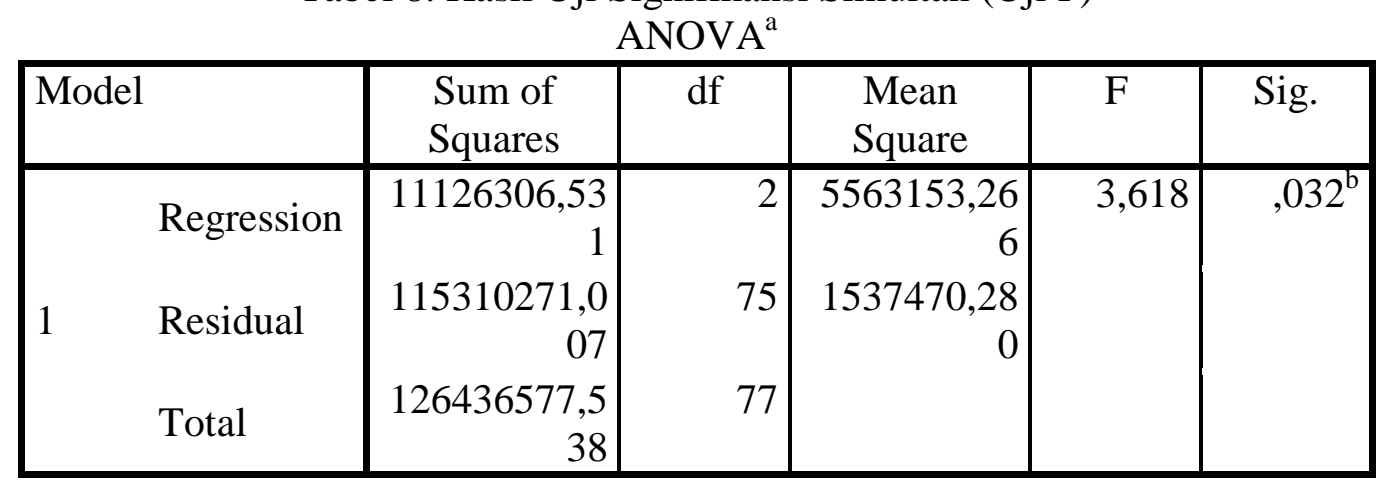

a. Dependent Variable: Harga Saham

b. Predictors: (Constant), PBV, PER

Nilai probabilitas dapat dilihat pada hasil perhitungan. Nilai F (sig.) yang dihitung pada tabel sebelumnya adalah 0,032 yang lebih kecil dari taraf signifikansi 0,05 , sehingga dapat disimpulkan bahwa model regresi linier taksiran layak untuk menjelaskan pengaruh antar variabel.

\section{PEMBAHASAN}

Harga saham merupakan salah satu indikator manajemen untuk berhasil mengelola perusahaan. Jika harga saham suatu perusahaan naik, investor dapat menilai apakah operasi perusahaan tersebut berhasil. "Harga saham terbentuk berdasarkan pertemuan antara penawaran untuk menjual dan permintaan untuk membeli saham" (idx.co.id). Anoraga (2014:59) dan Rusdin (2008:68) dapat melihat kepastian harga 
saham dari harga penutupan. Berdasarkan berbagai pengertian tentang harga saham, harga saham pada dasarnya adalah harga penutupan yang terbentuk dari interaksi pembeli dan penjual di pasar saham.

Tujuan dari penelitian ini adalah untuk mengetahui dan menganalisis pengaruh price-to-earning ratio dan nilai buku terhadap harga saham sub industri semen yang terdaftar di Bursa Efek Indonesia, yang dapat dijelaskan dari aspek-aspek sebagai berikut:

\section{Pengaruh Price Earning Ratio terhadap Harga Saham.}

Hipotesis ini dapat diterima, karena hasil statistik penelitian ini (uji T) mempengaruhi tingkat perolehan harga (per) mempengaruhi harga saham yang ditunjukkan oleh nilai-T $(0,188)$. Hasilnya adalah dampak yang paling dominan terhadap harga saham dan juga dapat memperoleh keuntungan perusahaan. Keputusan yang akan diambil oleh pemilik kami harus meningkatkan penjualan untuk menghasilkan keuntungan yang tinggi, sehingga hasil komersial kami akan lebih produktif dan meningkat. Meningkatkan. Investor memiliki kepercayaan dalam menanamkan modalnya pada perusahaan. Jika perusahaan memiliki kemampuan untuk menghasilkan laba bersih, investor tertarik untuk membeli tindakan tersebut, yang dapat meningkatkan harga pasar. Hasil penelitian ini juga didukung oleh hasil penelitian Hutami (2012) dan Wangary (2016).

Tingkat keuntungan harga (per) merupakan indikator investor untuk menentukan kemungkinan pertumbuhan di masa depan. Ini lebih luas dalam harga tindakan. Tingkat kenaikan harga (per) karena selain perkembangan harga saham dan perkembangan pendapatan perusahaan, juga karena merupakan indikator kepercayaan pasar dalam perspektif perusahaan. Indeks pendapatan harga (per) adalah analisis yang relatif sederhana, sehingga digunakan untuk analisis evaluasi persediaan, tetapi analisis ini akan berguna bagi investor untuk memusatkan penilaiannya. Batasan tingkat perolehan harga (per) signifikan jika manfaatnya negatif, dan tingkat perolehan harga (per) signifikan, dan keuntungan secara dramatis berfluktuasi pada rasio pendapatan harga. (Prastowo, 2010).

Tujuan dari price-to-earning ratio adalah untuk memahami bagaimana pasar mengevaluasi kinerja perusahaan yang tercermin dalam laba per saham. Rasio harga terhadap pendapatan menunjukkan hubungan antara pasar saham biasa dan laba per saham. Semakin tinggi rasio harga terhadap pendapatan per saham, semakin mahal harga saham dibandingkan dengan laba bersih per saham. Investor sering menggunakan angka ini untuk memprediksi kemampuan perusahaan dalam menghasilkan laba di masa yang akan datang (Prastowo, 2010).

Hasil penelitian ini sejalan dengan penelitian Yayuk Sulistyowati, 2014. Pengaruh earning per share (EPS), price-earning ratio (PER), dan dividend payment ratio (DPR) terhadap harga saham (penelitian empiris food and beverage perusahaan yang terdaftar di BEI), dengan menggunakan metode analisis regresi linier berganda. Hasil penelitian menunjukkan bahwa beberapa variabel independen dan variabel independen simultan (EPS, PER, DPR) berpengaruh signifikan terhadap harga saham. EPS merupakan variabel terpenting yang mempengaruhi harga saham.

Hasil penelitian juga sejalan dengan Elita Dwi Jayanti, 2015. Pengaruh Return On Investment (ROI), Earning Per Share (EPS) dan Price-to-earning Ratio (PER) terhadap Harga Saham Perusahaan Pertambangan Tercatat BEI Tahun 2011-2013 Gunakan 
regresi berganda. Hasil penelitian menunjukkan bahwa uji t menunjukkan bahwa return on investment (ROI) berpengaruh signifikan terhadap harga saham. Selain itu, variabel price-to-earning ratio (PER) menunjukkan pengaruh yang signifikan terhadap harga saham. Berdasarkan uji-t, variabel earning per share (EPS) berpengaruh signifikan terhadap harga saham. Dengan demikian dapat disimpulkan bahwa menerima hipotesis penelitian ini bahwa Price to Earning Ratio (PER) secara parsial berpengaruh terhadap harga saham sub industri semen.

\section{Pengaruh Price Book Value terhadap Harga Saham.}

Hasil penelitian menggunakan rumus (Fahmi, 2013:84) untuk menghitung nilai buku dari harga (market price per share: book value per share of Commonstock). Ratarata PBV 2015 hingga 2019 lebih tinggi dari 1 yang bisa dikatakan valuasi tinggi (overvalued). Walaupun diuji pengaruh nilai buku harga terhadap harga saham, pengaruhnya negatif $(2,685)$ dan signifikan. Oleh karena itu, berdasarkan asumsi pada Bab 2, asumsi bahwa nilai buku harga (X2) pada sub industri semen GoPublic berpengaruh signifikan terhadap harga saham (Y) telah diuji dan diterima oleh Bursa Efek Indonesia. .

Nilai buku per saham (BVS) adalah rasio yang membandingkan jumlah modal dengan jumlah saham beredar yang menunjukkan nilai sebenarnya dari saham perusahaan. Selain itu, nilai buku per saham (BVS) mencerminkan tingkat kepercayaan investor, karena nilai buku per saham (BVS) yang lebih tinggi menjamin keamanan investasi perusahaan.

Hasil penelitian ini menunjukkan bahwa perusahaan mengirimkan sinyal positif kepada investor karena adanya peningkatan nilai buku per saham (BVS). Jika Anda meningkatkan nilai buku per hektar (BVS), Anda juga akan meningkatkan kepercayaan investor terhadap perusahaan. Tingkat kepercayaan investor yang tinggi akan meningkatkan minat investor pada perusahaan investasi, sehingga meningkatkan harga saham perusahaan.

Fahmi (2013: 84) Salah satu indikator saham adalah nilai buku (PBV) yang banyak digunakan oleh investor dan analis untuk menentukan nilai wajar saham. Indikator ini dapat dibagi dengan harga saham di pasar modal dibagi dengan nilai buku saham tersebut. Dapat dikatakan bahwa saham dengan rasio PBV tinggi dinilai terlalu tinggi, sedangkan saham dengan PBV di bawah 1 tergolong undervalued atau undervalued. Salah satu indikator dari

saham adalah nilai buku harga (PBV) yang banyak digunakan oleh investor dan analis untuk menentukan nilai wajar saham. Indikator ini dapat dibagi dengan harga saham di pasar modal dibagi dengan nilai buku saham tersebut. Dapat dikatakan bahwa saham dengan proporsi PBV yang tinggi dinilai overvalued, sedangkan saham dengan PBV di bawah 1 tergolong undervalued atau undervalued.

Hasil penelitian ini menunjukkan bahwa perusahaan mengirimkan sinyal positif kepada investor karena adanya peningkatan nilai buku per saham (BVS). Jika Anda meningkatkan nilai buku per hektar (BVS), Anda juga akan meningkatkan kepercayaan investor terhadap perusahaan. Tingkat kepercayaan investor yang tinggi akan meningkatkan minat investor pada perusahaan investasi, yang akan meningkatkan harga saham perusahaan tersebut.

Hasil penelitian ini sesuai dengan hasil penelitian Nainggolan (2008), Sumarno dan Gunistiyo (2009), Malik dan lain-lain. (2012) dan Kusuma (2014) menunjukkan 
bahwa nilai buku per saham (BVS) berpengaruh positif terhadap harga saham. Hasil penelitian ini sejalan dengan hasil penelitian tahun 2016. Ida Ayu melihat pengaruh laba per saham, harga/pendapatan, dan nilai buku per saham terhadap harga saham. Hasil analisis menunjukkan bahwa earning per share (eps) berpengaruh positif terhadap harga saham, price-earnings ratio (by) berpengaruh positif terhadap harga saham, dan book value per share (bvs) berpengaruh positif. memengaruhi. Dampaknya pada harga saham.

Dengan demikian dapat disimpulkan bahwa hipotesis penelitian diterima, bahwa guide price (PBV) sebagian berpengaruh terhadap harga saham sub industri semen.

\section{KESIMPULAN}

Berdasarkan hasil analisis data dan pengujian hipotesis statisitik pada penelitian ini, maka dapat disimpulkan bahwa Price Earning Ratio dan Price Book Value secara simultan berpengaruh positif terhadap Harga Saham pada Sub Sektor Semen

\section{DAFTAR PUSTAKA}

Albert Kurniawan. 2014. Belajar Mudah SPSS Untuk Pemula. Yogyakarta : Mediakom.

Anoraga, Pandji dan Piji Pakarti, 2014. Pengantar Pasar Modal, Cetakan Kelima, PT Asdi Mahasatya, Jakarta.

Darmadji, Tjiptono dan Hendy M. Fakhrudin. 2011. Pasar Modal di Indonesia : Pendekatan Tanya Jawab. Jakarta : Salemba Empat

Fahmi, I. 2014. Pengantar Manajemen Keuangan, Teori dan Soal Jawab. Alfabeta Bandung.

Ghozali, Imam, 2017. Aplikasi Analisis Multivariate Dengan Program SPSS, Badan Penerbit Universitas Diponegoro, Semarang.

Husnan, Suad. 2015. Dasar-Dasar Teori Portofolio dan Analisis Sekuritas. Yogyakarta: UPP STIM YKPN

Irene Silvia Permata, Kertahadi, dan Topowijono (2014) dengan jurnal yang berjudul "Penilaian Saham Dengan Menggunakan Metode Price Earning Ratio (PER) dan Price Book Value (PBV) (Studi Pada Saham PT Bank Rakyat Indonesia (Persero), Tbk Yang Terdaftar Pada Bursa Efek Indonesia Periode 2003-2012)"

Jogiyanto. 2017. Teori Portofolio dan Analisis Investasi. Edisi 2, BPEE Yogyakarta. Yogyakarta.

Pratowo dan Rifka. 2010. Analisis Laporan Keuangan Konsep dan Aplikasi. UUP AMP YKPN : Yogyakarta

Pandansari, Fillya Arum. 2012. "Analisis faktor Fundamental Terhadap Harga Saham. Accounting Analysis Journal. ISSN 2252-6765. Hal 28-34 


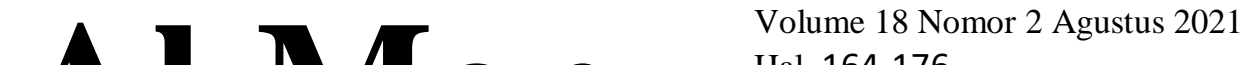 \\ Hal. 164-176 \\ e-ISSN : 2621-4377 \& p-ISSN : 1829-8524 \\ Hbmepage: https//e-jurnal.nobel.acid/index.php/akmen}

Ratih, Dorothea dan Apriatni E.P. 2013. “ Pengaruh EPS, PER, DER, ROE Terhadap Harga Saham Pada Perusahaan Sektor Pertambangan yang Terdaftar di Bursa Efek indonesia (BEI) Tahun 2010-2012”. Diponegoro Journal of Social and Politik. Hal 1-12.

Riduwan, 2015, Metode dan Teknik Menyusun Tesis, Penerbit Alfabeta Bandung

Rusdin (2008). Pasar Modal CetakanKedua. Bandung: Alfabeta

Sawir, Agnes. 2015. Analisis Kinerja Keuangan dan Perencanaan Keuangan Perusahaan. Jakarta: PT Gramedia Pustaka Utama.

Sugiyono.2018. Metode Penelitian Bisnis, Cetakan kedelapan Penerbit CV.Alfabe ta Bandung.

Sutrisno. 2017. Manajemen Keuangan Teori, Konsep dan Aplikasi . Yogyakarta : EKONISIA.

Susilawati, Christine Dwi Karya. 2016. "Pengaruh Rasio Keuangan Terhadap Harga Saham Pada Perusahaan Manufaktur”. Jurnal Ilmiah Akutansi. Vol 5 No 2. 2005. Hal 57-75. Universitas Kristen Maranatha. Jakarta.

Syamsuddin. 2017. Manajemen Keuangan Perusahaan.Jakarta: PT. Raja Grafindo Persada.

Tandelilin, Eduardus. 2017. Portofolio da Investasi: Teori dan Aplikasi. Edisi Pertama. Yogyakarta: Kansius 